\title{
Passwords
}

Volume 13 | Issue 1

Article 12

$12-20-2012$

\section{Modern Phaethon}

Kate Kennelly

kmk22010@mymail.pomona.edu

Follow this and additional works at: http://scholarship.claremont.edu/passwords

Cart of the Art and Design Commons, Creative Writing Commons, and the Photography Commons

\section{Recommended Citation}

Kennelly, Kate (2012) "Modern Phaethon," Passwords: Vol. 13: Iss. 1, Article 12. DOI: 10.5642/passwrd.20121301.12 Available at: http://scholarship.claremont.edu/passwords/vol13/iss1/12

This Poetry is brought to you for free and open access by the Journals at Claremont at Scholarship @ Claremont. It has been accepted for inclusion in

Passwords by an authorized administrator of Scholarship @ Claremont. For more information, please contact scholarship@cuc.claremont.edu. 


\section{Two Poems by}

Kate Kennelly

\section{Modern Phaethon}

He sailed the sun-filled carriage

Aloft the sky, arcing blindly when

He slipped, careened, and singed the earth,

A migraine of translucence.

In the ground, there opened

Graves of rays, flame fences rising;

Black rains of ash fell smothering,

Seared waters disappeared.

Above the gasping ground,

He hurtled through the blindness.

Inside his carriage cage,

He pled the gods to rend him,

To end his reeling ruin;

But the wheels of sun lurched on, and

His luminous cries, they shriveled,

Swallowed up in cindered air.

He steered to make a fatal turn,

But destruction held him circling,

Galloping through the glare.

The barrels of his eyes

Were smoking dust, his hands caught up

In the reins like chains,

As his misery swirled and reared

To the pit of the sky. 